\title{
İSLÂM TASAVVUFUNDA HZ. MERYEM
}

\section{Hatice Çubukcu*}

$\ddot{\mathbf{O} z}$

Hz. Meryem Hıristiyanlıkta olduğu gibi İslâm'da da hayırla yad edilen kutsal bir isimdir. İslâm alimlerinden onun peygamber olduğunu iddia edenler varsa da çoğunluğa göre o Allah'ın velî bir kuludur. Nitekim Hz. Meryem ilâhî vahye muhatap olmuş, bazen aracıyla bazen de doğrudan ilâhî olanla irtibata geçmiștir. Peygamberlerin varisleri kabul edilen velîlerin gösterdikleri kerâmetler Hz. Meryem'de de zuhur etmiştir. Mabette ibadet ederken ve Hz. Îsâ'nın doğumu esnasında olağan üstü şekilde yedirilip içirilmiştir. Tasavvufta Allah Teâlâ'nın sevdiği kulunu önceden seçtiğine inanılır, Hz. Meryem de Kur'ân-1 Kerim'de seçilmiş olarak vasfedilmektedir. Zira velâyetin kesbî tarafı olmakla beraber vehbî yönü daha ağırlıktadır. Hz. Meryem'in başına gelen zorluklara sabredip teslimiyet göstermesi onu, tasavvuftaki en yüce makam olarak görülen sıddîklık mevkiine yükseltmiştir. Her velî kul gibi o da gece gündüz ibadet ve taatla meşgul olmuş dünyadan yüz çevirmiştir. Bilindiği üzere Allah dostları günahlardan mahfuzdurlar. Hz. Meryem'in günahlardan uzak, tertemiz olduğu Kur'ân'da ve Hz. Peygamberin hadislerinde açıkça belirtilmiştir.

Hz. Meryem'in sayılan tüm bu özellikleri Allah dostu velî bir hanımın nasıl olması gerektiğini göstermektedir ve Hz. Meryem bu hususta müslüman kadınların örneği olmuştur.

Anahtar Kelimeler: Tasavvuf, Meryem, Velî, Sıddîk, Kerâmet

\section{MOTHER MARY IN SUFISM (ISLAMIC MYSTICISM)}

\begin{abstract}
Mary, as it is in Christianity, is also a sacred name in Islam. Although there are Islamic scholars who claim that she may be a prophet, according to the majority, she is a benevolent servant of Allah. Indeed, Mary had been in contact with the Divine and become the addressee of Divine Revelation sometimes through an intermediary and sometimes directly. The miraculous deeds which were revealed by saints who are accepted to be the inheritors of the prophets also appeared in Mary. When worshiping in the temple and during the birth of Jesus, she was fed in extraordinary ways. In Sufism, Allah (c.c) is believed to have chosen his beloved servants in advance, and Mary is also described as chosen in the Holy Qur'an. Because, although there is an aspect of
\end{abstract}

Article Types/Makale Türü: Research Article/Araştırma Makalesi

Received/Makale Geliş Tarihi:17/05/2019, Accepted/Kabul Tarihi: 01/09/2019

Doi: $10.26791 /$ sarkiat.566787

* Dr. Öğr. Üyesi, Ordu Üniversitesi İlahiyat Fakültesi, Tasavvuf Ana Bilim Dal1, haticecubukcu@odu.edu.tr

ORCID ID: https://orcid.org/0000-0003-2580-4120 
sainthood gained by striving, its aspect gained with the grace of Allah outweighs. Patience and submission of Mary in the face of hardship that she has experienced has raised her to the position of devoutness, which is regarded as the highest level in Sufism. Like every saint, she turned away from the worldly affairs and engaged in worship day and night. As is known, Allah's friends are protected from the sins. It is stated clearly in the Qur'an and in the hadiths of the Prophet Muhammad (PBUH) that Mary is immaculate and free from sins.

All of these characteristics mentioned show how a saint woman who is a friend of Allah should be, and Mary has been an example of Muslim women in this regard.

Keywords: Sufism, Mary, Saint, Devoutness (Siddiq), Miraculous Deed (Karama)

\section{GíRiş}

Kur'ân'da övgüyle söz edilen Hz. Meryem'in nebî yahut resûl olup olmadığı tartışılmış, sûfîler ise onu Allah dostu bir velî olarak vasıflandırmıştır. (Kuşeyrî, 2012, 1: 473; Râzî, 1989, 6: 282) Dolayısıyla tasavvufî düşüncede kadın velîlerin konumu büyük oranda Hz. Meryem'den hareketle şekillenmiştir. Tasavvuf yaşantısının hedefi insân-ı kâmil mertebesine erişebilmektir ve sûfîlere göre söz konusu hedefe erkekler gibi kadınlar da ulaşabilirler ki Hz. Meryem bu durumun en güzel örneklerinden biridir. (İbnü'l- Arabî, 2016, 4: 287) Nitekim Kur'ân-1 Kerîm'de onun seçilmiş olduğu (Âl-i İmrân 3/42) hadislerde de "Erkeklerden kemâle eren çoktur, kadınlardan ise İmrân kızı Meryem, Firavun'un Karısı Âsiye'den başkası kemâle ermemiştir" (Buhâri, "Enbiyâ", 34, 48; "Fedâil-u Ashâbi'n-Nebî", 32; Müslim, "Fadâilu's-Sahâbe", 70) buyrularak Hz. Meryem'in kemâle erdiği vurgulanmıştır. Âyetlerde geçen; erkek doğuracağını düşünerek karnındaki çocuğu Allah'a adayan $\mathrm{Hz}$. Meryem'in annesinin kız doğurduğunda yaşadığı hayal kırıklığına karşı, "Oysa Allah onun ne doğurduğunu biliyordu", (Âl-i İmrân 3/36) " Meryem'i güzel bir şekilde kabul etti ve güzel bir bitki gibi yetiştirdi" (Âl-i İmrân 3/37) şeklindeki ifadelerle Allah'ın Hz. Meryem'i bir kız çocuğu olarak kabul edip terbiye ettiği belirtilmiş dolayısıyla kadın olmanın manevî merhaleleri kat etmede bir engel olmayacağının altı çizilmiştir. Buradan hareketle sûfîler Hz. Meryem'in izinden giden ve kemâle eren kadın evliyâları "Meryem-i Sânî", "Nâib-i Meryem" şeklinde adlandırmışlardır. (bk. Attâr, 2002, 1: 95; Eflâkî, 1973, 1: $166,374)$

Hz. Meryem'in velî olarak görülme sebebi sadece yukarda zikrettiğimiz hususlarla sınırlı değildir. Çalışmamızda "hangi özelliklerinden dolayı Hz. Meryem bir kadın velî olarak kabul edilmiştir?" sorusunun cevabı aranacak, Hz. Meryem'in velâyet vasıfları tespit edilip sıralanacaktır. Şu bir gerçek ki tasavvuf klasikleri içinde Hz. Meryem'den daha ziyade işârî tefsirlerde söz edilmektedir. Velâyet vasıflarına kamilen haiz olan böylesi bir figürün diğer tasavvuf klasiklerinde daha kısıtlı bir şekilde yer alması şaşırtıcıdır. Söz konusu husus İslâm'da kendisine atfedilen yüce değere rağmen bir başka dinde ana karakterlerden biri olması hasebiyle duyulan çekinceden kaynaklanmış olabilir. İşârî tefsirlerde Hz. Meryem'le ilgili âyetlerin zahirî manasının yanında batınî yorumlarına da yer verilmiştir. Dolayısıyla makalede Hz. Meryem'le ilgili âyetlerin işârî yorumları da değerlendirilecektir.

Bahsedilen bölüme geçmeden önce Hz. Meryem'in faziletinden kısaca söz etmek faydalı olacaktır. Kur'ân'da "Hani melekler, "Ey Meryem Allah seni seçti, seni tertemiz yaptı ve seni dünya kadınlarına üstün kıldı" buyrulmuştur. (Âl-i İmrân 3/42) Âyetten hareketle, 
Hz. Meryem'in üstünlüğü tüm zamanlar için mi geçerlidir yoksa kendi yaşadığı dönemle mi sınırlıdır? sorusu tartışılmıştır. Hadislerde Hz. Meryem'le birlikte faziletleri zikredilen üç kadın daha vardır: Firavunun karısı Âsiye, Hz. Hatice, Hz. Fâtıma. -Bazı rivayetlerde Hz. Âişe de bu hanımlara eklenmiştir. - Söz konusu rivayetler şu şekildedir: "Rasulullah yere dört tane çizgi çizdi ve ardından sordu: Bunların ne olduğunu biliyor musunuz? Oradakiler "Allah ve Rasulü daha iyi bilir dediler. Bunun üzerine şöyle buyurdu: Cennet kadınlarının en faziletlileri Hatice, Fâtıma, Meryem ve Firavun'un karısı Âsiye'dir". (Nîsâburî, Müstedrek, 2:539, hadis no.3836) "Alemlerin en hayırlı kadınları dört tanedir: İmrân'ın kızı Meryem, Mezahim'in kızı Âsiye, Huveylid'in kızı Hatice, Muhammed'in kızı Fâtıma" (Tirmizî, "Menâkıb", 62) Zikredilen hadislerde olduğu gibi öncelik ve sonralık sıralaması yapılmadan bu 4 hanımın faziletinden bahseden hadisler olduğu gibi Hz Meryem'in bunlar içinde en üstünü olduğunu belirten hadisler de mevcuttur: "Cennetteki kadınların Meryem'den sonra lideri Fâtıma ve Hatice ve Firavunun karısı Âsiye'dir" (Zehebî, 1957, 2: 86) Hz Peygamber vefat anında kızı Hz. Fâtıma'ya "Sen cennetin seyyidesisin bunun istisnası İmrân'ın kızı Meryem'dir" demiştir. (Tirmizî, "Menâkıb", 61)Yine Hz Peygamber "Hatice benim ümmetimin kadınlarından üstün kılınmıştır, tıpkı Meryem'in bütün milletlerin kadınlarından üstün kılındığ 1 gibi" buyurmuştur. Bu hadisin bir başka versiyonunda "Zamanındaki Dünya kadınlarının en hayırlısı İmran kızı Meryem ve bu ümmetin kadınlarının en hayırlısı da Hatice'dir" (Buhârî, "Enbiyâ", 47; Müslim "Fedâli's-Sahâbe", 69) buyrularak Hz. Meryem'in üstünlüğü kendi zamanıyla sınırlandırılmıştır. Benzer ifadeler Hz. Âişe ve Hz. Fâtıma için de rivayet edilmiştir. Neticede bu hususta ihtilaf yaşanmış; Kurtubî, İbn Kesîr, Râzî gibi alimler Hz. Meryem'in tüm zamanların en faziletli kadını olduğunu savunmuş; Kuşeyrî, Taberî, Bursevî gibi isimler de Hz. Meryem'in kendi zamanının en faziletlisi olduğu görüşünü benimsemiştir. Sonuçta Hz. Meryem kıyamete kadar gelmiş ve gelecek tüm kadınların en üstünü iken Hz. Hatice ve Hz. Fâtıma kendi dönemlerinde yaşayan kadınların en faziletlisidir düşüncesi ağırlık kazanmaktadır. (Schleifer, 2003, 94)

Burada küçük bir parantez açmakta yarar vardır. İslam geleneğinde Hz. Meryem ile Hz. Fâtıma arasında hususi bir bağ kurulmuştur. (Gündüzöz, 2016, 265) Özellikle Şîa'da Hz. Fâtıma'ya Hıristiyanlıktaki Hz. Meryem'in rolü verilmiştir. (Bilici, 2003, 28:102) Her ikisi de "mater dolorosa" yani acılı annelerdir (Schimmel, 1999, 33) ve zamanla efsanevî, kült karakterlere dönüşmüşlerdir. Aşırı bâtınî gruplarda Şiî etkisi ağırlıkta olmakla beraber sünnî sûfî çevrelerde de zaman zaman Şiî ve Hıristiyanlık etkisiyle Hz. Fâtıma'yla ilgili sahih olmayan bazı rivayetlere itibar edilmiştir. Burada unutulmaması gereken bir husus da sûfî çevrelerde ehl-i beyt sevgisinin ayrı bir önemi haiz olduğudur. Hz. Fâtıma ile Hz. Meryem arasında bağ kuran en yaygın rivayet şu şekildedir: Hz. Peygamber kıtlık olan bir dönemde acıkır, kızı Hz. Fâtıma da ona iki parça çörek ve biraz et gönderir. Daha sonra Hz. Peygamber yemeği alıp Hz. Fâtıma'nın evine götürür ve birlikte yemeyi teklif eder. Hz. Fâtıma tabağı açınca içinin et ve ekmekle dolu olduğunu görür ve şaşır, neticede bunun Allah katından gönderildiğini anlar. Hz. Peygamber "bu sana nereden geldi" diye sorunca da "Allah'tan geldi Allah dilediğini hesapsız rızıklandırır" der. Bunun üzerine Hz. Peygamber, "Seni İsrailoğulları hanımlarının efendisine denk kılan Allah'a hamdolsun" buyurur. Sonra Hz. Ali, Hz. Hasan, Hz. Hüseyin ve tüm ehl-i beytini toplar, hepsi karınları doyuncaya kadar o yemekten yer; buna rağmen yemek olduğu gibi kalır, hiç azalmaz. Hz. Fâtıma da yemeği komşularına dağıtır. (Zemahşerî, 2016, 1:928; Beyzâvî, 2011, 1:373-374; İbn Kesîr, 1984, 4:1240; Bursevî, 2014, 3:93) 
Bunun yanında Hz. Fâtıma "betûl, sâfiye" gibi Hz. Meryem'e atfedilen sıfatlarla anılmıştır. Neticede Hz. Fâtıma Hz. Meryem'in sahip olduğu sâfiye-kâmile makamına ulaşmış üstün bir şahsiyettir.

\section{Bir Kadın Velî Olarak Hz. Meryem Ve Özellikleri}

Hz. Meryem tasavvufta ve dînî edebiyatta kullanılan sembol kavramlardan biridir. Özellikle tasavvufta nefs-i kâmilenin (sâfiye-zekiye) sembolü olarak görülmüştür. (Âlûsî, ts., 3:143) Nefsin emmâre makamı dînî literatürde dişil unsurlarla anlatılır, nefsin en üst sâfiye makamı ise Hz. Meryem'de tecelli etmiştir. Dolayısıyla Hz. Meryem dişilikten kadınlığa geçişteki tekamülün, hatta kadınlığın da ötesinde cinsiyetten cinsiyetsizliğe geçişin örneğidir. (Sargut, 2016, 9) Sûfîler bu durumu "er" olmak şeklinde açıklar. Er olmak cinsiyetle alakalı değildir. Nitekim sûfîlere göre kıyamet günü din erlerinin bulunduğu meydanda "Ey Erler" nidası yükselince ilk öne çıkacak olan Hz. Meryem'dir. (Nahşebî, 1999, 91) Hz. Meryem bir başka deyişle arınmış nefistir (nefs-i zekiye) ve onun gibi nefsini arındıran kişi kemâle ermiş ruhu doğurur ve artık onda konuşan bu ruhtur. (Ay, 2011, 123)

Tasavvuf edebiyatında da Hz. Meryem'le ilgili ifadelere rastlamak mümkündür. Özellikle Ahmed Yesevî'nin (ö. 562/ 1166) halifesi Hakîm Süleyman Ata'nın (ö. 582/1186) manzum "Hazreti Meryem Kitabı" dikkat çekicidir. Söz konusu eser Orta Asya'da derviş meclislerinde Ahmed Yesevî'nin hikmetleri gibi koro halinde okunmuştur. (Tekcan, 2004, 186)

Hz. Meryem'in sûfîler tarafından velî olarak vasıflandırılmasında etken olan hususlar şu şekildedir: Vahye-ilhâma mazhar olması, kerâmet göstermesi, Allah tarafindan seçilip, terbiye edilmesi, sıddîka oluşu, takvası, teslimiyeti, itaati ve adanmışlığı, temiz ve iffetli olup günahtan korunmasıdır.

Şüphesiz sayılan bu vasıflar Hz. Meryem'in peygamber olduğunu iddia edenlerin de delilleridir. İbn Hazm, Kurtubî, Âlûsî gibi alimler Hz. Meryem'in vahye muhatap olması, mucize göstermesi, temiz ve seçilmiş olmasından dolayı resul olmasa da nebî olabileceğini iddia etmişlerdir. Ancak makalede sûfîlerin gözüyle Hz. Meryem konusu işlendiğinden söz konusu vasıflar onun velâyetinin delilleri olarak zikredilecektir. Kadî İyâz'a göre Hz. Meryem ve Hz. Âsiye'yi peygamber değil de velî olarak kabul etmenin şu șekil pratik faydası da vardır; Şayet bu iki hanıma peygamber dersek onlardan sonra hiç bir hanım o yüksek mertebeye ulaşamaz ancak Hz. Meryem ve Hz. Âsiye iki velîye olarak düşünülürse her çağda Meryemlerin Âsiyelerin bulunabileceği kabul edilmiş olur ve ümmetin kadınları onlara benzemeye çalışır.(Schleifer, 2003, 107) Çoğunluğun velî bir kul olarak kabul ettiği Hz. Meryem'in velâyet özellikleri aşağıda sıralanmıştır.

\subsection{Hz. Meryem'in Vahye-İlhâma Mazhar Olması}

Tasavvufu diğer İslâmî disiplinlerden ayıran en temel vasıf "ilhâm"1 bilgi kaynaklarından biri olarak kabul etmesidir. Sûfîler ilhâmî bilgiye, keşf, mârifet, yakîn, vâkıa, havâtır, ilm-i ledün, vâridât gibi farklı isimler vermişlerdir. İlham, kalbe gelen Hakk kaynaklı bilgidir. (Kâşânî, 2004, 78) İlhamî bilgi doğrudan alınabilineceği gibi melek aracılığıyla da elde edilir. Sûfîler ulaşılan bu bilgiyi delil olarak kabul ederler, zahir ulemâsı ise ilhâmî bilgiyi delil kabul etmez. (Cürcânî, 2014, 70) Sûfîlere göre ilhâmî bilgiyi elde edebilmek için günahlardan arınmış velî bir kul olmak gerekir. Sûfî riyâzet ve mücâhede ile arınarak, gelene hazırlık yapar. Neticesinde ilhâm Allah Teâlâ'dan kulun kalbine feyz olunur. Sufiler kendilerine gelen ilhâmın şeytanın bir aldatmacası olup olmadığından emin olmak için onu iki âdil hakem Kur'ân ve sünnete 
tâbi tutmuşlar, mazhar oldukları ilhâm Kur'ân ve sünnete uygun ise onunla amel etmişlerdir.

Kur'ân'daki ifadelerden anlıyoruz ki Hz. Meryem bazen melek aracılığıyla bazen de doğrudan, vahye muhatap olmuștur. Tıpkı onun gibi Hz. Mûsâ'nın annesi de vahiy almıştır. Dolayısıyla bu iki hanımın peygamber olabileceği iddia edilmiştir. Bu noktada şu sorulabilir; Vahiy almak peygamber olmayı gerektirir mi? İmam Mâtürîdî'ye göre gerektirmez. O, Hz. Mûsâ'nın annesiyle ilgili âyetlerde geçen vahiy tabirinin resûl olmayı gerektiren vahiy olmadığını aksine kalbe bir bilgi yerleştirme manasındaki ilhâm olduğunu zikreder. (Mâtürîdî, 2018, 11: 19-20; Benzer görüş için bk. Râzî, 1989, 6:304) Nesefî'nin vahiy sınıflandırması meseleyi aydınlatmaktadır. Nesefî'ye göre vahy ikiye ayrılır: Özel anlamda vahiy, genel anlamda vahiy. Özel vahiy peygamberlere özgüdür, genel vahiy ise evliyâ ve asfiyâya mahsustur. Bu anlamdaki vahye ilhâm da denir. (Uludağ, 2016, 269) Hz Meryem'e gelen vahyi bu çerçevede değerlendirebiliriz.

Ebussuûd Efendi'ye göre de Hz. Meryem'in vahiy alması vahiy meleğini görmesi onun peygamberliğine değil Allah katındaki yüceliğine delalet etmektedir.( Memiş, 2016, 136) Nitekim Hz. Meryem'in Cebrâil'den vahiy aldığı kesindir ancak ona Kur'ân, İncil gibi insanlığa iletilecek bir kitap ya da özel bir mesaj verilmemiştir.( Schleifer, 2003, 125) Ashap da Cebrâil'i Dihye Kelbî suretinde görmüştür ve Cebrâil'i görmeleri onları peygamber yapmamıştır. (Kurtubî, 2003, 4:202)

İşârî tefsirlerde Hz. Meryem'e mihraptayken bahşedilen rızkın, yiyecek anlamında maddi rızıktan ziyade; ilim, hikmet, hakikat, marifet, halvet cenneti gibi manevi rızka işaret ettiği belirtilmiştir.( Ay, 2011, 127-128) Söz konusu rızka şaşıran Hz. Zekeriyya da aklı temsil eder ve ledünnî rıkkı anlamakta zorlanır.(Kâşânî, ts., 1:189)

Hz. Meryem'in doğum sırasında yediği hurma da manevi rızık olarak yorumlanmıştır. Meryem nasıl ki, hurma ağacını sallayıp üzerine taze hurma düşürdüyse kalb Meryem'i de zikir ağacını, "lâ ilâhe illallah" zikriyle sallayınca Meryem'in üzerine rabbanî müşâhadeler ve ilahî keşifler düşer. (Bursevî, 2014, 12:53) Yani hurma ağacinın silkelenmesinin istenmesinden maksat kemâle eren nefsin tefekkür ile harekete geçirilip ondan marifet ve hakikatlerin devşirilmesidir. Üstten hurmaların dökülmesi $\mathrm{Hz}$. Meryem'in ledün ilmine, (Konuk, 2005, 11:434) hakikate ermesine işaret ederken altından ırmak akıtılması tabii ilimlere ulaşması anlamındadır. (Kâşânî, ts., 1:728)

"Kitapta Meryem'i de an. Hani ailesinden ayrılarak doğu tarafinda bir yere çekilmişti" (Meryem 19/16) âyetinde geçen doğu tarafi kutsî âlem olarak tevil edilmiştir. Söz konusu mekan kemâle eren nefsin ailesinden yani nefsanî ve tabiî kuvvetlerden uzaklaşarak rûhulkudüs ile iletişime geçtiği yerdir. $\mathrm{Bu}$ alan kalp perdesiyle korunmuştur. (Kâşânî, ts., 1:725)

Sûfîlere göre mârifet, ilhâmî bilgi, kalb aracılığıyla elde edilir. Meryem'le ilgili âyetlerin işarî tefsirinde Hz. Îsâ'nın Meryem'den doğması; manevi gelişim sonunda nefsten kalbin doğması şeklinde yorumlanmıştır. (Ay, 2011, 130) Zira Hz. Îsâ Hz. Meryem'e müjdelenen ve kainattaki bütün harfleri kendinde toplayan kalptir.

Tasavvufta marifete erebilmek için her şeyden önce bu hususu dert etmek gerekir. Niyâzî-i Mısrî "Derman arardım derdime, derdim bana derman imiş" sözleriyle buna işareteder. Mevlana'da aynı şeyi vurgular, ona göre insan dertli olmalıdır zira kişiye yol gösteren derdidir. Hz. Meryem dahi doğum sancısı çektiğinde baht ağacına ulaşır, hurma ağcının dibine gider. Onu oraya götüren derdidir. Neticede kuru ağaç meyve verir. Beden de Meryem'e benzer her birimizin bir İsa'sı vardır. Bizde dert meydana 
gelirse İsa'mız doğar. Dert olmazsa İsa geldiği o gizli yoldan gider aslına kavuşur biz de ondan mahrum kalmış oluruz. (Mevlânâ, 2013, 22) Izdırab inkişaf için zaruridir ve Meryem doğum sancıları içinde tatlı hurmaların üzerine yağması ile mükafatlandırılır. (Schimmel, 1999, 100)

Neticede Hz. Meryem'in Allah Teâlâ ile kurduğu yakın irtibat onun peygamberliğinden ziyade kâmil, sıddîka bir mümin olduğunun göstergesidir demek yanlış olmaz.

\subsection{Hz. Meryem'in Kerâmet Göstermesi}

Kerâmet, nübüvvet davası olmayan mümin ve salih amel sahibi bir kimseden harikulade şeylerin zuhur etmesidir. (Cürcânî, 2014, 78) Mucizeler peygamberlere, kerâmetler de velîlere ve salih müminlere aittir. (Serrâc, 1996, 309) Evliyanın kerâmetinin hak olduğunda ittifak vardır. Sûfîler Hz. Meryem'in başına gelen olağanüstü halleri kerâmet olarak değerlendirmişlerdir. Kuşeyrî ve Hucvîrî; "Zekeriyyâ mihrapta bulunan Meryem'in yanına her girişinde orada rızık bulur, ve bunlar nereden geliyor? diye sorar, Meryem ise o Allah'ın nezdindendir derdi", (Âl-i İmrân 3/37) "Hurmanın şu kuru dallarını sallayıver sana devşirilmiş yaş hurmalar düşecektir." (Meryem 19/25) âyetlerini kerâmetin Kur'ân'dan delilleri olarak zikreder. (Kuşeyrî, 1999, 439; Hucvîrî, 1996, 348; Serrac, 1996, 313) Rivayete göre Zekeriyyâ Meryem'in yanına her girdiğinde yazın kış meyveleri kışın da yaz meyveleri bulmakta idi. (İbn Kesîr, 1984, 4:1240) Doğumu sırasında yaslandığı kuru hurma ağacından da kış mevsimi olmasına rağmen taze hurmalar dökülmüştür. Zikredilen ilk âyette geçen "Küllema" ifadesinden de evliyanın kerâmetinde devamlılık şart olmadığı hükmü çıkartılmıştır. Çünkü Zekeriyyâ vasıtasız rızka erdiği için Meryem'le ilgilenmeyi bırakmamış onun yanına devamlı bir şekilde gitmiştir. (Kuşeyrî, 2012, 1:285; İbn Acîbe, 2011, 2:72)

Hz. Meryem'in peygamberliğini kabul edenler, yukarda geçen hususları mucize olarak adlandırır. Oysa ki mucizenin şartlarından biri inkarcılara karşı meydan okumadır. Hz. Meryem'in hikayesinde ise böyle bir durum yoktur. (Bursevî, 2014, 12:50)

Zemahşerî gibi bazı mu'tezile alimlerine göre Meryem'in nasibi olan bunca fazilet, ya Zekeriyyâ'nın ya da Îsâ'nın mucizesidir (irhas). (Zemahşerî, 2016, 1:936) Şüphesiz Zemahşeri kerâmete karşı olduğu için bu görüştedir. Kerâmeti inkar edenler kerâmeti kabulün, mucizenin değerini düşürdüğü, velî ile nebîyi aynı seviyeye indirdiği kanısındadırlar. (Uludağ, 2016, 338-339)

Bilindiği üzere Hz. Meryem'den doğum yapmak için yaslandığı hurma ağacını sallaması istenmiştir, bu husus müfessirlerin dikkatini çekmiştir. İbn Atâ'nın yorumuna göre Hz. Meryem mabetteyken hiç bir dünyevi meşguliyeti yoktu ve kendini tamamen Allah'a adamıştı bu yüzden kendisine vasıtasız rızık geliyordu, İkinci durumda ise gönlüne evlat sevgisi düşmüştü ve rızık için ağacın dallarını sallaması istendi. (Kuşeyrî, 2012, 3:431432; Kurtubî, 2003, 11:186; Gürer, 2018, 108) İbn Acîbe bu yoruma karş1 çıkar çünkü Hz. Meryem sıddîkadır ve sıddîklar konumlarından daha alt makama düşmezler ancak kemâllerini daha da artırabilirler nitekim Ebû Abbâs el-Mürsî'ye göre Hz. Meryem mabetteyken sebeplere tevessül etmeden sadece kerâmet gösteriyordu ikinci durumda ise yakîni kemâle ermiş olduğu için sebepler alemine dönmüştü dolayısıyla ikinci hali birincisinden daha kâmil idi. (İbn Acîbe, 2011, 5:509)

Mekki'ye göre Hz. Meryem'in ağacı silkelemesinde farklı bir amaç vardır. Zira hurma elle silkelenip düşürülecek meyve değildir. Allah Teâlâ Hz. Meryem'e verdiği değeri göstermek için onun elini bir alet kılmış, (Mekkî, 2004, 3:56) eliyle dokunduğu kuru hurma ağacı yeşerip taze meyve vermiştir. Buradan hareketle gelenekte Hz. Meryem eli 
ve ondan ilhâmla Hz. Fâtıma eli mübârek kabul edilmiş, pek çok ananevi uygulamaya konu olmuştur.

Kuru hurma ağacının taze meyve vermesiyle ilgili bir diğer yorum da şu şekildedir; Allah Teâla kuru hurma kütüğünü salla diyerek ölüleri diriltmenin misalini $\mathrm{Hz}$ Meryem'e göstermiş oldu.(Kurtubî, 2003, 11:184) Böyle bir mucizeye kadir olan Allah Hz. İsa'yı da babasız yaratmaya kadirdir. Dolayısıyla yaşadıkları Hz. Meryem'i teskin etmeye yöneliktir.

Bursevî'ye göre Meryem'i ayıplayanlar da bu olağanüstü hallere şahit olunca, babasız çocuk meydana gelmesini imkansız görmeyecektir.(Bursevî, 2014, 12:51) Neticede Hz Meryem'de açığa çıkan olağanüstü haller hem onu teselli etmiş hem de diğer insanları ikna etmiştir. (Zemahşerî, 2016, 4:166) Bir peygamber mucize veya bir velî kerâmet gösterdiğinde o devrin insanlarının çoğu tarafından yadırganır. Onları delilik, sapıklık, sihirbazlıkla suçlarlar. İnsanların az bir kısmı ise bilir ki çoğunluğun bulunduğu yerden sefere çıkıp ayrılanlar akılların alışık olmadığı ve gözlerin görmediği garip bilgiler ve acayip hallerle geri dönerler. (Bursevi, 2014, 12:56) Meryem de bu yolculuğa çıkmış, kendinde olağanüstü haller zuhur etmiştir. Söz konusu halleri mucize değil de kerâmet olarak adlandırmak Hz. Meryem'in kamile vasfina daha uygundur.

\subsection{Hz. Meryem'in Allah Tarafından Seçilip Terbiye Edilmesi}

Hz. Meryem'den bahseden âyetlerde iki defa onun seçilmiş (istifa) olduğu vurgulanmıştır. "Bir gün melekler Meryem'e şöyle seslendiler: Meryem Allah seni şeçti (istifa), tertemiz yaptı ve dünya kadınlarına üstün kıldı (istifa). (Âl-i İmrân 3/42) Hz. Meryem hemcinslerinde farklı çok sayıda nimete nail olmuştur. Dolayısıyla âyetin yorumu şu şekilde yapılmıştır: Melekler ona dedi ki: "Ey Meryem Allah seni evinin (Beyti Makdis) hizmeti için seçti. Oysa daha önce hiç bir kadını kabul etmemişti. Seni sırf ibadeti için görevlendirdi ve bizzat kendi rızıklandırarak, başkasına muhtaç etmedi. Allah seni çirkin görülen kötü işlerden korudu. Meleklerle konuşmayı, babasız salih bir evlat dünyaya getirmeyi böylelikle dünya kadınlarına üstün olmayı sana nasip etti. (İbn Acîbe, 2011, 2:81) Kuşeyrî'ye göre birinci istifadan kastedilen; kerâmet, mertebe ve durumunun yüceliğiyle seçkin kılınmasıdır, ikinci istifa ile de babasız İsa'ya gebe kalmasıyla hiç bir kadının kıyamete kadar ona benzemeyecek olması kastedilmiştir. (Kuşeyrî, 2012, 1:289)

Meleklerin Meryem'e seslenerek "Ey Meryem Allah seni seçti tertemiz yaptı ve dünya kadınlarına üstün kıldı" (Âl-i İmrân 3/42) demesini Kaşani, ruhani güçler, nefsi zekiye'ye "İstidadından dolayı Allah seni seçti ve kötülüklerden temizledi. Seni şehvani nefislere üstün kıldı" şeklinde yorumlamıştır

Peygamberler Allah'ın seçkin kullarıdır. Allah tarafından seçilip onun gözetiminde terbiye edilirler. Serrâc'a göre seçilmişlik "istifa" sadece peygamberlere özgü bir durum değildir, müminler için de geçerlidir. (Serrâc, 1996, 73-74) Dolayısıyla Allah'ın velî kulları onun daha önceden seçtiği kullarıdır demek yanlış olmaz. Velâyetin kesbî tarafi olmakla beraber vehbî yönü ağırlıktadır. Yani Allah Teâlâ ezeli ilminde seçtiği kullarını özel kabiliyetlere haiz bir şekilde yaratır. O kul da sahip olduğu yüksek kabiliyeti çerçevesinde gayret göstererek ulaşılabilecek en üst manevi makamlara ulaşır. Katettiği bu yolda hocası, rehberi bizzat Allah Teâlâ'dır. Sûfîler bu sebepten "Beni Rabbim terbiye etti ve gerçekten güzel terbiye etti" hadisini (Aclûnî, ts.,1:84) önemserler. Kaşanî, Allah'ın Hz. Meryem'i doğrudan eğitmesini "Benim nasıl çocuğum olur" âyetiyle (Âl-i İmrân 3/47) açıklar. Âyetin batınî yorumunda Hz. Meryem "nefis kendisine bir beşer eli değmemişken yani bir şeyhin terbiyesinden geçmemiş̧en nasıl 
kemâle erer" demek istemiştir. Buna karşılık Allah Teâlâ da şöyle buyurur "İşte böyledir, Allah dilediğini yaratır. Cezb ve keşf ile dilediğini seçer, terbiye ve talim olmaksızın ona kalp makamını bahşeder" (Kâşânî, ts., 192) Aynı şekilde Rûzbihân-1 Baklî de Hz. Meryem'in "bunlar Allah katından" ifadesini, elde ettiği rızkın -ki bu marifet, hikmettir- ibadet ve taatının karşılığında değil Allah'ın lutfu sonucu ulaştığına delil sayar. (Ay, 2011, 127)

Ayrıca âyette geçen Allah'ın Meryem'i kabul ettiği yönündeki ifade onu kutlu olanların yoluna ilettiği anlamına gelmektedir. (Kurtubî, 2003, 4:180)

Allah Teâlâ'nın Hz. Meryem'i güzel şekilde kabul etmesini Kuşeyrî; Allah'ın velîlerine sahip çıktığı gibi Meryem'e sahip çıkması, onu sırf ibadetiyle meşgul etmesi, iffetli bir şekilde terbiye etmesi olarak yorumlamıştır. Güzel kabulün bir göstergesi Hz. Zekeriyyâ gibi bir peygamberi onun bakımıyla görevlendirmesidir. Bir yoruma göre de güzel kabulün alameti bütün işlerini $\mathrm{Hz}$. Zekeriyyâ'ya bırakmamasıdır. Şöyle ki, Hz. Zekeriyyâ onun yanına her girdiğinde rızık görürdü bundan amaç Allah'ın dostlarının işini başkasına yüklemediğinin bilinmesidir. Dolayısıyla kim Allah'ın velîlerinden birine hizmet ederse velîlerinden dolayı bir meşakkate maruz kalmaz. Allah Teâlâ Onu bir bitki gibi yetiştirmiştir. O, Öyle güzel bir bitkidir ki Hz. Îsâ gibi meyvesi olmuştur. (Kuşeyrî, 2012, 1: 283-284) Neticede Hz. Meryem Allah'ın seçkin velî kullarından biridir.

\subsection{Hz. Meryem'in Sıddîka Oluşu, Teslimiyyeti}

Sıddîk, sözünde ve inancında doğru olan, bunu davranışlarıyla kanıtlayan kimsedir. (İsfahânî, 2012, 583) Sıddîk, sıdkın mübalağa sigasıdır, çok doğru, kendinde sıdk galip olan demektir. (Kuşeyri, 1999, 292) Siddîklar; peygamberler, salihler ve şehitlerle aynı gruptandır. Nitekim âyet-i kerimede "Kim Allah ve Resulüne itaat ederse onlar Allah'ın nimet verdiği peygamberler, sıddîklar, şehitler ve salihlerle beraberdir" (en-Nisâ 4/69) buyrulmuştur. Bununla beraber İbrahim, İdris peygamberde olduğu gibi "sıddîk" kelimesi peygamberleri vasfetmek için de kullanılmıştır. el-Mâide sûresinde Hz. Meryem "sıddîka" olarak anılmış (el-Mâide,75) dolayısıyla peygamberlere benzetilmiştir. (Memiş, 2016, 116)

Tasavvufta ise sıddîk olma en yüce makama sahip olma anlamına gelmektedir. İbnü'lArabî'ye göre nebilikle sıddîklık arasında başka bir makam yoktur. (İbnü'l-Arabî, 2016, 2:33) Yani sıddîklık makamının üstünde sadece nübüvvet makamı vardır. (Kâşânî, 2004, 328) Dolayısıyla sıddîk, peygamberden sonra gelen kişidir. Bu hususa değinen Hucvîrî, sıddîk, peygamberler müstesna bütün mahlukatın önde olanıdır, der. (Hucvîrî, 1996, 157) Ona göre, sufî kelimesinin türediği safâ ve safvet de siddîk olanın sifatıdır. Safânın aslı kalbin ağyardan temizlenmesi, fer'i ise dünyadan elin boş olmasıdır. Bu ikisi de Hz. Ebû Bekir Sıddîk'ın sıfatıdır. Dolayısıyla sufî̀ taifesinin önderi, imamı odur. (Hucvîrî, 1996, 112) Hz. Ebû Bekir'in miraç hadisesinde olduğu gibi Hz Meryem de başkalarının inanmadığı şeyi tasdik ettiği için sıddîk unvanını almıştır. Allah'ın emrini kabul için âyet ve alamet istememiştir. (Amulî, 2015, 129) Hakîm Tirmizî'ye göre Hz. Meryem -Hz Zekeriyya'nın aksine- müjdelendiği şeyle ilgili bir delil gösterilmesini istemediği için Allah onu övmüş ve kitabında onu sıddîka diye isimlendirmiştir. (Tirmizî, 2018, 174) Daha sonra değinileceği gibi sıddîk ve sıddîka sıfatıyla öne çıkan $\mathrm{Hz}$ Ebu Bekir ve $\mathrm{Hz}$ Meryem lakaplariyla da birbirine benzemektedirler, nitekim Hz.Ebu Bekir azat olmuş anlamına gelen "atik", Hz Meryem de aynı anlamda "muharrar" şeklinde adlandırılmıştır. 
Sıddîkiyyet makamı geçmiş ve gelecekte bir kadının sahip olabileceği en üst makamdır. Bursevî'ye göre meydana çıkmak ve davet sahibi olmak esaslarına dayandığından peygamberlik kadınlara uygun değildir. Dolayısıyla onların kemâl halleri sıddîkiyyettir ki bu makam daha önce de belirttiğimiz gibi nübüvvete yakındır. (Bursevî, 2014, 3:107)

Söz konusu makamda halis bir niyete sahip olmak önemlidir. Hz. Meryem'in sıddikiyyeti onun niyetinin sağlamlığını göstermektedir. (Bursevî, 2014, 3:84) Kâşânî'ye göre Hz. Meryem'in sıddîk oluşunda annesinin halis bir niyete sahip olmasının da etkisi vardır. Zira annenin aldığı gıdalar karnındaki çocuğun bedeninde etkili olduğu gibi niyeti ve nefsinin halleri de çocuğun maneviyâtı üzerinde etkili olur. (Kâşânî, ts., 1:188)

Burada akla şöyle bir soru gelebilir: Hz. Meryem'in "benim oğlum nasıl olur" şeklindeki ifadesi böylesi bir makam sahibi için eksiklik değil midir? Bu ifade şüphe barındırmaz mı? Bu hususta Füsus şarihi Avni Konuk'un açıklaması şu şekildedir:

"Meryem'in "benim oğlum nasıl olur?" sözüyle şaşırması Kudret-i İlâhiye'den şüphe ettiği için değil, İbrahim'in "Yarabbi ölüyü nasıl dirilttiğini bana göster", Üzeyir'in "Allah onları öldükten sonra nasıl diriltir", Zekeriya'nın, "zevcem kısır olduğu halde benim oğlum nasıl olur", sözlerinin benzeridir. Kudretin zuhura gelmesini temaşa zevkini talep etmektedir. Zira müminlerin avam kısmı iman ile iktifa ederlerse de kamil olan kısım hakikatini talep eder." (Konuk, ts., 24)

Nitekim Hz. Meryem'in "Bunlar Allah katındandır" demesi tevhidin özüdür. Allah'ın kullarına rızık göndermesi, ihsanda bulunması yalnızca kendisinin iradesine bağlıdır. İnsanların ibadet ve taatlarının karşılığı değildir. (Kuşeyrî, 2012, 1:285)

Hz. Meryem teslimiyetin simgesidir. (Altıntaş, 1986, 22) Hz. Meryem'in hamileliğine gösterdiği teslimiyet onun Rabb'inin iradesine tam anlamıyla tabi olduğunu kanıtlamaktadır. O halde neden "keşke bundan önce ölseydim" demiştir? (Meryem 19/23) Kuşeyrî muhtemel sebepleri sıralamıştır, şöyle ki: Hz. Meryem bu sözü kavminden çekindiği için söylemiş olabilir. Çünkü o kendisini suçlayarak kınayacaklarını ve ahlaksızlıkla itham edeceklerini anlamıştı. Bir başka ihtimale göre bu sözü kavmine acıdığı ve onun yüzünden başlarına bir azap gelmesin diye söylemiştir. Ya da Hz. Meryem şöyle demek istemiştir."Keşke bundan önce ölseydim de benim yüzümden Îsâ Allah'ın oğlu, Meryem karısı gibi ithamları duymasaydım", bir diğer yorum da "Keşke bundan önce bana nazik davranıldığı ve başıma gelen şu sıkıntıyla karşılaşmadiğım zamanda ölseydim" şeklindedir. Sonuncu ve daha sûfîyane yorumda ise Hz. Meryem "Keşke bundan önce kalbimin Allah'tan başka hiçbir şeye bağlanmadığ zaman ölseydim." demeyi kastetmiş̧ir. (Kuşeyrî, 2012, 3:430-431) Neticede bu şekil ifadeler sorumluluk bilinci yüksek şahsiyetlerde rastlanan bir durumdur. Öyle ki $\mathrm{Hz}$. Ebu Bekir'in yüklendiği emanetin ağırlığından keşke kuş olsaydım, keşke hayvanların yediği ot olsaydım tarzında ifadeler kullandığı rivayet edilir. (Mekkî, 2004, II: 315; Serrâc, 1996,131) Benzer ifadeler Hz. Ömer ve Hz. Bilâl için de rivayet edilir, Hz Ömer yerden bir saman çöpü alarak "Keşke şu saman çöpü olsaydım", Hz. Bilal de "Keşke annem beni doğurmasaydı" demiştir. (İbn Acîbe, 2011, 5:501) Tüm bu ifadelerden anlaşıllyor ki Hz. Meryem'in "Keşke bundan önce ölseydim" sözü onun manevi açıdan eksikliğini göstermemektedir aksine kendine yüklenen emanetin ağır sorumluluğunun bilincinde olduğunu izhar etmektedir. 


\subsection{Hz. Meryem'in Takvâsı, Zühdü ve Adanmışlığı}

Hz. Meryem doğumundan itibaren mabede adanmış burada kendine ayrılan "mihrab" adlı bölümde gece gündüz ibadet ve taat ile meşgul olmuştur. Meryem ismini almasında bu hususun etkisi vardır zira Meryem, o bölge halkının dilinde "ibadet eden kadın, Rabb'in hizmetkarı" demektir. (Zemahşerî, 2016, 1:922; Râzî, 1989, 6:277; Bursevî, 2014, 3:87) Burada küçük bir parantez açmakta yarar vardır. Bilindiği üzere Kur'ân-1 Kerîm'de bizzat ismiyle zikredilen tek kadın Hz. Meryem'dir. Oysa ki, kadim kültürde hür kadınların ismi saygıdan dolayı ulu orta zikredilmez, "eş, hane halkı" ş̧eklinde kinaye yollu ifade edilirdi. Ne var ki, Hıristiyanların Hz. Meryem ve Hz. Îsâ hakkında uygunsuz yakıştırmalarından dolayı Kur'ân-1 Kerim'de onun kulluk yönünü vurgulamak için Arapların câriyeler için kullandıkları gibi Hz. Meryem bizzat ismiyle zikredilmiştir. (Sargut, 2016, 24)

Hz. Meryem'in mabedde inzivaya çekilip gece gündüz ibadetle meşgul olması, İslâm tasavvufunda nefs tezkiyesi için uygulanan halvet, çile yöntemlerini hatırlatmaktadır.

Hz. Meryem'in mabette kaldığı zamanlarda dünyalık hiçbir meşguliyeti ve tasası yoktur. Yemeği dahi vasitasız kendisine verilmektedir. Bu bağlamda annesinin Hz. Meryem'i mabede hür (muharraran) olarak adadığını belirtmesi dikkat çekicidir. (Âl-i İmrân, 3/35) "Muharraran" ifadesi Tüsterî, Sülemî, Rûzbihân-1 Baklî, Kuşeyrî gibi müfessirlerin çoğu tarafından dünya ve ehlinin köleliğinden, nefsinin hevasından azat olmak şeklinde yorumlanmıştır. (Ay, 2011, 125) Arapçada katıksız ve arı olan her şeye hür denir. Hz. Meryem'in hür olması Aziz ve Celil Allah'a adanmış, dünya işlerinden azade kılınmış anlamındadır. (Kurtubî, 2003, 4:177) İmam Mâtürîdî Müzzemmil Sûresi sekizinci âyetin tefsirinde dünya ile ilişkisini kesip ahirete yönelmesi sebebiyle Meryem'e "betûl" isminin verildiğini söyler. (Memiş, 2016, 116)

Hz Meryem'in sürekli ibadetle meşgul olduğunu vurgulayan bir başka delil de âyette geçen "kunût" sözüdür. (Âl-i İmrân 3/43) Zira burada kunûttan maksat, sürekli taât içinde bulunmaktır. (İbn Acîbe, 2011, 2:82)

Azrâ lakabıyla anılan Hz. Meryem'in bekar olması zahidliğinin vasıflarındandır. Onun bu vasfi Râbia el-Adeviyye (ö. 185/801) gibi ilk İslam velîlerine örnek olmuştur. Ancak bu husus çok yaygınlık kazanmamış, zahidliğin fiziğin ötesinde kalbî bir durum olduğu anlayışının yerleşmesiyle müslüman kadın evliyalar, evliliği manevî ilerleme de engel olarak görmemişlerdir. Nitekim evli ve çocukları olan Hz. Fâtıma, erkeklerden uzaklaşan anlamına da gelen "betûl" (İbnü'l-Arabî, 2016, 13:117) olarak adlandırılmış, müslüman kadınların manevî liderlerinden biri haline gelmiştir. Neticede mühim olan kalbin Allah'tan başka bir şeyle meşgul olmamasıdır. Tasavvufta asıl olan halk içinde Hakk ile olmayı başarabilmektir.

Hz. Meryem'in zühdünde dikkat çeken bir başka husus "susma orucu" tutmasıdır. (Meryem 19/26) Tasavvufta nefsi tezkiye araçlarından biri de az konuşmak, susmaktır. Ancak Hz. Meryem'in uyguladığı gibi susma orucu tutmayı Hz. Peygamber yasaklamıştır. Yasaklanan mutlak sukuttur. Sûfîlere göre zikre devam ederek konuşmayı kesmek ise makbuldür. (Bursevî, 2014, 12:53) Âyette sefih karşısında sukut etmenin gerekli olduğuna da işaret vardır. Ayrıca âyette Allah'tan başka şeylere yönelmekten sakınmaya da işaret vardır. Şu halde sâlike gereken nâsût aleminden ayrılıp dilini Allah'ın dışındakileri zikretmekten engellemektir. Ta ki kul, yol alıp, hakikat menziline ulaşsın. (Bursevi, 2014, 12:53) İbnü'l-Arabî'ye göre susmakla erkekler gibi kadınlar da abdal mertebesine erişebilir. Nitekim bir sûfîye abdalın sayısı sorulmuş $\mathrm{O}$ da kırk kişidir demiş, "niçin adam demedin?" diye sorulunca "bazen 
içlerinde kadınlar da olabilir" cevabını vermiştir. Hz. Peygamber'in kemâl sahibi kadınlardan saydığı Hz. Meryem ve Hz. Âsiye de bu durumun delilidir. (İbnü'l-Arabî, 2016, 6:206)

Hz. Meryem'in sustuğunda işaretle konuşması da İslam tasavvufunda bâtınî yoruma kapı açar. Zira bâtınî yorum manayı bütünüyle ortaya koymaz ona işaret eder. Bu yüzden sûfî tefsirlerine işarî tefsir denilmiştir.

Hz. Meryem'in susması, zahir ehline gizli hakikatlerin anlatılmamasının işareti olarak görülmüştür. Ayrıca Allah Teâlâ Hz. Meryem ve Hz. Îsâ kıssasında Hz. Meryem'in susmasını Hz. Îsâ'nın konuşmasının mukaddimesi kılmıştır. İsa'nın nutku nasıl Meryem'in sukutundan sonra açıldıysa, tâlibin kalbi (Îsâ'sı) de nefis (Meryem) sözden kesildiği zaman dile gelecektir. (Kâşânî, ts., 1:174)

Hz. Meryem'in zahidliğiyle ilgili gösterişsiz, siyah ve uzun elbise giyindiği rivayet edilmiştir. Neticede Hz. Meryem muttakî zâhid bir kul idi.

\subsection{Hz. Meryem'in İffetli ve Temiz Olması, Günahtan Korunması}

Kur'ân'da "Yâ Meryem Allah seni seçti ve tertemiz yaptı" buyrulmuştur. (Âl-i İmrân 3/42) Âyette geçen temiz ifadesine hem maddî hem de manevî mana vermek mümkündür. Hz. Meryem, sürekli mabedde bulunması hasebiyle maddi kirlerden temiz idi hatta onun hayız görmediği yönünde rivayetler vardır. (Râzî, 1989, 6:305) Manevi açıdan temiz olması ise onun günahlardan korunmuş olmasıdır. Nitekim Meryem'in annesi şöyle dua etmiştir: "Onu ve soyunu kovulmuş şeytandan senin korumana bırakıyorum" (Âl-i İmrân 3/36) Hadis-i şerifte "Yeni doğan hiç bir çocuk yoktur ki şeytan ona doğumu esnasında dokunmuş olmasın. Çocuk şeytanın dokunmuş olmasından dolayı ağlar. Meryem ve oğlu ise bundan müstesnadır." (Buhâri, "Enbiyâ", 46; Müslim, "Fedâil", 146) Âyet ve hadislerden anlaş1ldığg üzere Hz. Meryem ve oğlu günah işlemekten uzaktırlar. Peygamberlerin bir özelliği de ismet sıfatıdır. Dolayısıyla Hz. Meryem'in peygamber olduğunu iddia edenlere göre onun günahsız oluşu önemli bir delildir. İslam tasavvufunda peygamberler masum olduğu gibi velîler de mahfuzdur. Dolayısıyla $\mathrm{Hz}$ Meryem de günahlardan mahfuzdur. Bu hususla ilgili küçük bir parantez açmakta yarar vardır: Velînin günahtan mahfuz olması peygamberler gibi günahsız olması anlamına gelmez. Velî'den şer, fesat, afet, hata zuhur edebilir, fakat velî bu gibi günahlarda 1srar etmez. (Kuşeyrî, 1999, 438) Yani velî günahta 1srardan korunmuştur.

Kur'ân'da Hz. Meryem'in iffetli oluşuna vurgu yapılmış, namusunu koruduğu açıkça belirtilmiştir. (et-Tahrîm 66/12; el-Enbiyâ 21/91) Lakabı olan "betûl"ün bir manası da erkeklerden uzaklaşan demektir. (İbnü'l-Arabî, 2016, 13:117) Meleğin Hz. Meryem' e yakışıklı bir erkek gibi görünmesi onun için bir imtihandır ve bu yolla onun ne kadar iffetli olduğu gösterilmiştir. (Zemahşerî, 2016, 4:54) Böylelikle Hz. Meryem'in kötülüklerden ne kadar sakındığı ve iffet sahibi olduğu ortaya çıkmıştır. (İbn Acîbe, 2011, 5:496)

Kur'ân'da Hz. Yûsuf ve Hz. Meryem iki iffet abidesi olarak yer alır, tehlike anında verdikleri tepkilerden hareketle Hz. Meryem'in Hz.Yûsuf'tan daha dirayetli olduğunu söylemek yanlış olmaz şöyle ki; Hz.Yûsuf hakkında Yüce Allah "Andolsun kadın onu arzu etmişti. Eğer Rabbinin doğruyu gösteren delilini görmeseydi $\mathrm{O}$ da onu arzu etmişti (fakat rabbinin delilini gördügü için azmetmedi)" (Yûsuf 12/24) buyurmuştur. Oysa ki meleği genç bir delikanlı gibi gören Hz. Meryem'in tavrı şu şekilde anlatılmıştır: "(Meryem) şöyle dedi: Ben senden Rahman'a sığınırım, Eğer Allah'tan korkuyorsan (bana dokunma)" (Meryem 19/18) Hz. Meryem'in kendi bu işe azmetmediği gibi insan 
suretindeki meleği de bu işten nehyetmiştir. (Amulî, 2015, 107,109) Olay anında hiç bir tereddüt yaşamamıştır.

\section{Sonuç}

Hz. Meryem İslam tasavvufunda insan-1 kâmil olarak kabul edilir zira bizzat Hz. Peygamber onun kemâle erdiğini ifade etmiştir. Kur'ân-1 Kerîm'de de seçkin, sıddîka, temiz, iffetli gibi kemâlini vurgulayan vasıflarla zikredilmiştir. Hz. Meryem'in bir kadın olarak böylesi yüce bir makama erişmiş olması tasavvuftaki kadın görüşüne etki etmiş neticede de tasavvufî düşüncede diğer İslamî disiplinlere nazaran daha olumlu bir kadın algısı ortaya konmuştur. Nitekim tasavvufta kadınların da erkekler gibi manevi merhaleleri aşıp hakikate ulaşabileceği kabul edilmiş, tabakât kitaplarında Râbia elAdeviyye gibi çok sayıda kadın velîden bahsedilmiştir.

Hiç şüphesiz, Hz. Meryem'i kemâle erdiren sıfatlarının başında onun sıddîka oluşu gelir. Öyle ki, tasavvufta sıddîklık nübüvvetin bir altındaki makamdır ve Hz. Meryem Allah Teâlâ'nın kendisi için takdir ettiği kadere itirazsız teslim olduğundan bu makama ulaşmıştır. O teslimiyetin simgesidir. Hz. Meryem'i üstün kılan bir diğer özelliği onun seçilmiş olmasıdır. Daha dünyaya gelmeden annesi tarafından mabede adanmış, kız olmasına rağmen annesinin adağı kabul edilmiş ve bizzat Allah Teâlâ tarafından güzel bir bitki gibi yetiştirilip, terbiye edilmiştir. Hz. Isâ'nın doğumuna kadar mabedde kendine ayrılan kısımda ibadetle meşgul olmuş, dünyadan ve onun kirlerinden uzak durmuş, tertemiz, her türlü dünya bağından azade yaşam sürmüştür. Karşısına yakışıklı bir delikanlı şeklinde çıkan Cebrâil'e karşı takındığı tavrıyla da ne denli iffetli olduğunu göstermiştir. Gerek Cebrâil aracılığıyla gerekse doğrudan vahye muhatap olması onun ne boyutta yüce bir makama sahip olduğunun delillerindendir. Bunun yanında onda zuhur eden olağan üstü hadiseler de sayılan diğer özellikleri gibi Allah'ın velî kullarından biri olduğunun kanıtlarındandır.

Neticede zikredilen bu özellikler nefs-i kâmile mertebesine ulaşmış insan-1 kâmilin vasıflarıdır ve bu yönüyle $\mathrm{Hz}$. Meryem müslüman sûfî kadınların ilhâm kaynağı olmuştur.

\section{Kaynakça}

Aclûnî, İsmail b. Muhammed. Keş̧ü'l-Hafâ, thk. Şeyh Yusuf b. Mahmud, 2 Cilt. b.y.: Mektebetü'-1 İlmi'l-Hadis, ts.

Altıntaş, Hayranî. Tasavvuf Tarihi. Ankara: Ankara Üniversitesi İlahiyat Fakültesi Yayınları, 1986.

Âlûsî, Şihâbuddîn Mahmud. Rûhu'l-Meânî fî Tefsîri'l-Kur'âni'l- Azîm ve's-Seb'i'lMesânî, Beyrut: Dâru İhyâi't-Turâsi'l-Arabî, ts.

Amulî, Cevâdî. Celâl ve Cemâl Aynasında Kadın. çev. Ejder Okumuş. İstanbul: İnsan Yayınları, 2015.

Attâr, Ferîdüddin. Tezkiretü'l Evliyâ. çev. Süleyman Uludağ. 2 Cilt. İstanbul: Mavi Yayınc1lık, 2002.

Ay, Mahmut. "İşarî Tefsirlerde Hz. Meryem". İstanbul Üniversitesi İlahiyat Fakültesi Dergisi 25 (2011): 123-138. 
Eflâkî, Ahmed. Menâkibü'l-Ârifin Ariflerin Menkıbeleri, çev. Tahsin Yazıcı. 2 Cilt. İstanbul: Hürriyet Yayınları, 1973.

Bilici, Faruk. "Massignon, Louis". Türkiye Diyanet Vakfi İslâm Ansiklopedisi. 28: 100103. Ankara: TDV Yayınları, 2003.

Bursevî, İsmail Hakkı. Rûhu'l Beyân Kur'ân Meâli ve Tefsiri. çev. Ali Hüsrevoğlu. 23 Cilt. İstanbul: Erkam Yayınları, 2014.

Cürcânî, Seyyid Şerif. Ta'rîfât Tasavvuf Istılahları. çev. Abdülaziz Mecdi Torun. İstanbul: Literâ Yayıncılık, 2014.

Gündüzöz, Güldane. "Kur'ân-1 Kerim Işı̆ğında Mümin Kadın Şahsiyeti -Zahir ve Batın İlimleri Arakesitinde Bir bakış-". Uluslararası Kişilik ve Karekter İnşâsında Dinin Yeri Sempozyumu. (10-12 Haziran 2016). ed. Yavuz Ünal- Şevket Pekdemir- Yusuf Bahri Gündoğdu- Orhan İyibilgin- Sait Kar. 1:259-270. Ordu, 2016.

Gürer, Betül. Gönül Gözüyle Kur'ân İbn Atâ Tefsiri. İstanbul: H Yayınları, 2018.

Hucvîrî, Ebü'l-Hasen. Keşfü'l-Mahcûb Hakikat Bilgisi, çev. Süleyman Uludağ. İstanbul: Dergah Yayınları, 1996.

İbn Acîbe, el-Hasenî. Bahrü'l Medîd fî̀ Tefsîri'l Kur'âni'l-Mecîd. çev. Dilaver Selvi. 12 Cilt. İstanbul: Semerkant Yayınları, 2011.

İbn Kesîr. Hadislerle Kur'ân'ı Kerîm Tefsiri. çev. Bekir Karlığa-Bedrettin Çetiner. 16 Cilt. İstanbul: Çağrı Yayınları, 1984.

İbnü'l-Arabî, Muhyiddin. Fütûhât-l Mekkiyye. çev. Ekrem Demirli. 17 Cilt. İstanbul: Litera Yayıncilık, 2016

İsfahânî, Râgıb. Müfredât Kur'ân Kavramları Sözlüğü. çev. Abdülbaki Güneş - Mehmet Yolcu. İstanbul: Çıra Yayınları, 2012.

Kâdî Beyzâvî. Muhtasar Beydâvî Tefsiri. çev. Şadi Eren. 2 Cilt. İstanbul: Selsebil Yayınları, 2011.

Kâşânî, Abdürrezzâk. Tasavvuf Sözlüğü. çev. Ekrem Demirli. İstanbul: İz Yayıncılık, 2004.

Kâşânî, Abdürrezzâk. Tefsir-i Kebir Te'vilât. çev. Vahdettin İnce. 2 Cilt. İstanbul: Kitsan Kitap, ts.

Konuk, Ahmed Avni. Mesnevî-i Şerif Şerhi, haz. Selçuk Eraydın-Mustafa Tahralı. 13 Cilt. İstanbul: Kitabevi, 2005.

Konuk, Ahmed Avni. Risale-i Meryem (Hz. Meryem ve Hz. İsâ'ya Dair Risale-i Mühimme). sad. A. Sadık Yivlik. Dizgi. İlhami Sorkun. ts..

Kurtubî, Muhammed b. Ahmed. el-Câmiu li-Ahkâmi'l-Kur'ân. çev. M. Beşir Eryarsoy. 20 Cilt. İstanbul: Buruc Yayınları, 2003.

Kuşeyrî, Abdülkerim. Tasavvuf İlmine Dair Kuşeyrî Risalesi. çev. Süleyman Uludağ. 2 Cilt. İstanbul: Dergah Yayınları, 1999.

Kuşeyrî, Abdülkerim. Kur'ân-ı Kerim Tefsiri Letâifu'l-İşârât. çev. Mehmet Yalar. 6 Cilt. İstanbul: İlkharf Yayınevi, 2012.

Mâtürîdî, Ebû Mansur. Te'vilâtü'l-Kur'ân Tercümesi. çev. Fadıl Ayğan. 17 Cilt. İstanbul: Ensar Yayınları, 2018. 
Mekkî, Ebû Tâlib, Kûtü'l-Kulûb Kalplerin Azı̆̆g, çev. Muharrem Tan. 4 Cilt. İstanbul: İz Yayıncilık, 2004.

Memiş, Murat. "İmam Mâtürîdî ve Ebussuûd'un Tefsirlerinde Hz. Meryem". Dokuz Eylül Üniversitesi İlahiyat Fakültesi Dergisi. 153 (2016): 101-141.

Mevlânâ, Celâleddîn-i Rûmî, Fîhi Mâ Fîh, çev. Ahmed Avni Konuk. İstanbul: İz Yayınc1lık, 2013.

Nahşebî, Ziyâüddîn. Silku's- Sulûk Ariflerin Yolu. çev. Mustafa Çiçekler-Halil Toker. İstanbul: İnsan Yayınları, 1999.

Nîsâbûrî, Hâkim. el-Müstedrek ale's-Sahîhayn. 3 Cilt. Beyrut: Daru'l-Kutubi'l-İlmiyye, 1990.

Râzî, Fahruddîn. Tefsîr-i Kebir Mefâtîhu'l-Gayb. (ed.). Ahmet Hikmet Ünalmış. 23 Cilt. Ankara: Akçă̆ Yayınları, 1989.

Sargut, Cemâlnur. Kadınlık Makamının En Yücesi Meryem Sûresi -2. İstanbul: Nefes Yayınları, 2016.

Schimmel, Annemarie. Ruhum Bir Kadındır. çev. Ömer Enis Akbulut. İstanbul: İz yayınc1lik, 1999.

Schleifer, Aliah. Peygamber mi Evliya mı? İslâm'ın Kutsal Meryem'i. çev. İbrahim Kapaklıkaya. İstanbul: Gelenek Yayıncılık, 2003.

Serrâc, Ebû Nasr. el-Lüma' İslam Tasavvufu. çev. H. Kamil Yılmaz. İstanbul: Altınoluk, 1996.

Tekcan, Münevver. "Hazret-i Meryem Kitabı". İstanbul Üniversitesi Edebiyat Fatültesi Türk Dili Ve Edebiyatı Dergisi. 33 (2005): 207-238.

Tirmizî, Hakîm. Hatmu'l Evliyâ Velîliğin Sonu. çev. Salih Çift. İstanbul: İnsan Yayınları, 2018.

Uludağ, Süleyman. Tasavvufun Dili, İstanbul: Ensar Neşriyat, 2016.

Zemahşerî. el-Keşşâf. çev. Muhammed Çoşkun. 6 Cilt. İstanbul: Türkiye Yazma Eserler Kurumu Başkanlığı Yayınları, 2016. 